Elsevier Editorial System(tm) for Trends in Food Science and Technology

Manuscript Draft

Manuscript Number:

Title: Options for producing a warm-water fish in the UK: Limits to "Green Growth"?

Article Type: Special Issue: Sustainable Food

Corresponding Author: Dr David Colin Little, Ph.D

Corresponding Author's Institution:

First Author: David C Little, PhD

Order of Authors: David C Little, PhD; David Colin Little, Ph.D; Francis J Murray, PhD; Ekram M Azim, PhD; William A Leschen, MSc; Kathleen A Boyd, MSc; James A Young, PhD; Andrew Watterson, PhD

Abstract: This paper explores the development of a sustainable production system for tilapia and the research implications involved with ensuring commercial viability of such a system for UK farmers. The tilapia is a warm water fish with firm texture, white flesh and mild taste quite similar to a cod or haddock. Whilst tropical in origin it is thought to be highly suitable for low cost aquaculture in temperate zones with the potential to be a more sustainable source of food with fewer environmental impacts than other substitutes. Drawing on a literature review and findings from technical trials the paper will review and compare two production systems - novel Activated Suspension Technology (AST) and conventional Recirculating Aquaculture Systems (RAS) - considering their feasibility in terms of potential and financial viability for scaling up to commercial production of tilapia and their environmental and sustainability benefits. The review concludes that AST based only on microbial floc is currently uncompetitive with RAS in a UK context although the approach has benefits that might be incorporated in a new generation of mixed systems. Refinement of such systems needs to occur with potential adopters and could be part of diversification of mixed farms. Such development might further enhance the ethical values of fish produced in small-scale, modular RAS. 
Table 1 Water and land productivity of tilapia RAS compared to selected intensive open-water production systems (after Phillips et al., 1991 reported in Timmons et al 2002).

\begin{tabular}{llllll}
\hline & & $\begin{array}{l}\text { Water } \\
\text { productivity } \\
\mathrm{kg} \mathrm{m}^{3-1}\end{array}$ & $\begin{array}{l}\text { Production } \\
\text { intensity } \\
\mathrm{mt} \mathrm{ha}^{-1} \mathrm{yr}^{-1}\end{array}$ & \multicolumn{2}{c}{$\begin{array}{l}\text { Ratio of land and water } \\
\text { Water to RAS use }\end{array}$} \\
\hline RAS & Nile tilapia & 10 & 1,340 & 1 & 1 \\
Intensive & Nile tilapia & 0.05 & 17.4 & 200 & 77 \\
ponds & Paneid shrimp & $0.05-0.09$ & $4.2-11$ & $110-200$ & $120-320$ \\
Raceways & Channel catfish & $0.2-0.3$ & 3 & $400-500$ & 446 \\
\hline
\end{tabular}


Table 2. Comparison of production parameters in experimental RAS and AST growout systems for O. niloticus (source: Murray et al. 2007)

\begin{tabular}{|c|c|c|c|c|}
\hline \multirow[b]{2}{*}{ Parameter } & \multicolumn{4}{|c|}{ Source } \\
\hline & $\begin{array}{l}\text { Murray et al } \\
2007\end{array}$ & $\begin{array}{l}\text { Hargreaves } \\
2006\end{array}$ & $\begin{array}{l}\text { Rackocy } \\
2002\end{array}$ & $\begin{array}{l}\text { Avnimelech } \\
1999\end{array}$ \\
\hline Production system & RAS & AST & $\mathrm{AST}$ & AST \\
\hline Indoor/ Outdoor & indoor & indoor & outdoor & outdoor \\
\hline Dietary crude protein $\%$ & 30.4 & 32 & 32 & 20 \\
\hline $\begin{array}{l}\text { Secondary carbohydrate } \\
\text { source }\end{array}$ & na & none & none & cellulose \\
\hline 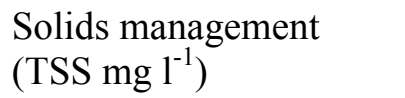 & $<2$ & $250-1000$ & $\begin{array}{l}898(100- \\
1960)\end{array}$ & no data \\
\hline Culture unit & $2.8 \mathrm{~m}^{3} \operatorname{tanks}$ & $1.5 \mathrm{~m}^{3}$ tanks & $\begin{array}{l}200 \mathrm{~m}^{3} \\
\operatorname{tank}\end{array}$ & $\begin{array}{l}50 \mathrm{~m}^{2} \\
\text { earthen } \\
\text { pond }\end{array}$ \\
\hline Culture days & 107 & no data & 201 & 30 \\
\hline Mean temperature $\left({ }^{\circ} \mathrm{C}\right)$ & 29.4 & no data & 28.5 & - \\
\hline Mean start weight (g) & 19.1 & 41 & 73.6 & 112 \\
\hline Mean end weight (g) & 405 & 134 & 678 & 218 \\
\hline Cumulative SGR $(\%)^{\mathrm{b}}$ & 2.8 & 1.27 & $1.11^{\mathrm{a}}$ & $1.31^{\mathrm{a}}$ \\
\hline Final biomass $\mathrm{kg} \mathrm{m}^{3-1}$ & 25.6 & 9.8 & 13.7 & 16.5 \\
\hline Cumulative $\mathrm{FCR}^{\mathrm{c}}$ & 1.1 & 1.83 & 1.9 & 2.17 \\
\hline Cumulative $\mathrm{PCR}^{\mathrm{d}}$ & 3.1 & no data & - & 2.18 \\
\hline Survival & 98.2 & no data & 81 & 94.8 \\
\hline $\begin{array}{l}\text { Water productivity } \mathrm{kg} \\
\mathrm{m}^{3-1}\end{array}$ & 8.1 & no data & 9.7 & no data \\
\hline
\end{tabular}




\section{REVIEW: Options for producing a warm-water fish in the UK: Limits to "Green Growth"?}

David C. Little, Francis J. Murray, Ekram Azim, William Leschen, Kathleen Grady, James A. Young and Andrew Watterson.

Institute of Aquaculture, Department of Marketing and Public Health Research Group, University of Stirling, Stirling, FK9 4LA,U.K. (Tel +44 1786 467923;fax: +44 1786-467200; email:dcl1@stir.ac.uk)

This paper explores the development of a sustainable production system for tilapia and the research implications involved with ensuring commercial viability of such a system for UK farmers. The tilapia is a warm water fish with firm texture, white flesh and mild taste quite similar to a cod or haddock. Whilst tropical in origin it is thought to be highly suitable for low cost aquaculture in temperate zones with the potential to be a more sustainable source of food with fewer environmental impacts than other substitutes. Drawing on a literature review and findings from technical trials the paper will review and compare two production systems - novel Activated Suspension Technology (AST) and conventional Recirculating Aquaculture Systems (RAS) considering their feasibility in terms of potential and financial viability for scaling up to commercial production of tilapia and their environmental and sustainability benefits.

The review concludes that AST based only on microbial floc is currently uncompetitive with RAS in a UK context although the approach has benefits that might be incorporated in a new generation of mixed systems. Refinement of such systems needs to occur with potential adopters and could be part of diversification of mixed farms. Such development might further enhance the ethical values of fish produced in small-scale, modular RAS.

\section{Introduction}

Seafood consumption in the UK is on the rise (Seafish, 2006), although in comparison with other countries the amounts consumed are relatively small. In recent years a high media profile has affected UK consumers' interest in and perceptions of seafood. Some of the many issues making headlines range from the health benefits of including fish in the diet (Britton, 2006), to concerns with the safety of consuming both wild and farmed fish (Foran, Carpenter, Hamilton, Knuth \& Schwager, 2005). Declining wild fish stocks (Worm et al., 2006) and the quality of the marine environment (Royal Commission on Environmental Pollution, 2004) are also frequently brought to the public eye, creating a complex picture for the public. The diversity of contradictory messages received by the public instigates confusion (Young, Grady, Little, Watterson \& Murray, 2006).

Most of the fish used for human consumption currently comes from wild capture fisheries; however seafood from aquaculture is growing rapidly and is set to account for $50 \%$ of the worlds' food fish in the near future (FAO, 2007a). The rapid growth in aquaculture production is attributed to declining wild stocks even as these continue to be exploited for use in feed for farmed carnivorous aquatic species as well as for other forms of intensive livestock production. This is a major cause of controversy (White, O'Neill \& Tzankova, 2004) 
The largely negative view of aquaculture in the UK, as a highly intensive, specialised and vertically integrated business model contrasts with traditional practice elsewhere around the world. In Asia where global aquaculture remains concentrated, low trophic species such as carps and tilapias still dominate farmed production and much of this is based on pond-based semi-intensive or extensive systems. This type of aquatic farming is characterised by the high proportion of feed being produced through natural food webs in situ (Azim \& Little, 2006). Traditionally aquaculture was one component of mixed farming systems and geared to meet subsistence and local market needs (Beveridge \& Little, 2002). But soaring demand and limitations of these systems has fuelled a major scale-up in the world wide production of farmed 'seafood' over the last two decades both to meet local and, increasingly, international markets. The shrimp boom in the mid-1980s-90s based on a limited number of species (mainly Penaeus spp.) and more latterly Nile tilapia (Oreochromis niloticus ) and Asian river catfish ( Pangasius hypothalmus) have both spread and intensified, particularly in developing countries where land, water and labour are abundant and cheap.

Tilapias have been heralded as a seafood commodity with major potential (Josupeit, 2005). In contrast to shrimp production the rapid scale-up in tilapia production has attracted little criticism from environmental groups and instead been portrayed as a white fish alternative to species higher up the food chain (Marine Conservation Society, 2006). They are being produced in a wide range of production systems and countries in the Tropics and Sub-tropics unlike the Asian river catfish where significant production is concentrated in one area-the Mekong Delta of Vietnam. It might be argued that these factors increase the relative opportunity for sustained growth of tilapia production, especially as despite the levels of growth, prices have remained relatively firm (Josupeit, 2005).

Global production of tilapias has soared over the last decade (FAO, 2007b) with particularly significant growth in South America for export markets and China for both internal and export markets (Josupeit, 2007a, b). This tropical species that originated in Africa is now the $6^{\text {th }}$ most popular seafood choice in the USA (National Fisheries Institute, 2005) and major aquaculture producers turn to tilapia as a new species to invest in (Josupeit, 2007b). Although major centres of tilapia production are in Asia, South and Central America and Africa, culture has also become established in North America and Europe in the last few years. Tilapia production in the UK has been mainly characterised by high profile failures to date (Bunting \& Little, 2005). This review assesses the technological options for tilapia production within insulated agricultural buildings proposed as a potential option for rural diversification (Little, 2006).

\section{Towards greener aquaculture}

In light of the contradictory messages conveyed in the media, consumer understanding of the ethical and human health issues surrounding aquaculture is understandably confused; however there is still a strong desire for fresh, traceable fish amongst UK consumers (Young et al, 2006). The natural shoaling behaviour of many fish species make the farming of fish at high density both practical and ethical $(>100$ 
$101 \mathrm{~kg} \mathrm{~m}^{-3}$ ) provided that nutritionally balanced diets can be cost effectively delivered

102 and the quality of the water can be maintained (Ebeling, Timmons \& Bisogni, 2006).

103

104

105

106

107

108

109

110

111

112

113

114

115

116

117

118

119

120

121

122

123

124

125

126

127

128

129

130

131

132

133

134

135

136

137

138

139

140

141

142

143

144

145

146

147

148

149

150
Most of the fish species raised intensively are top carnivores most dependent on high quality feeds conventionally based on fishmeal and oils derived from wild fisheries. These feed ingredients are subject to contamination with persistent organic compounds and their amplification through the food chain (Worm et al, 2006). The relative risk of consumption of such farmed fish compared to fish of wild origin and other food stuffs for different groups is the focus of increasing consumer and scientific interest (Foran, Good, Carpenter, Hamilton, Knuth \& Schwager, 2005; Ellingsen \& Aanondsen, 2006).

The environmental costs of feed and water supply to aquaculture are also becoming a major cause of criticism (Naylor et al., 2000); particularly for carnivorous species but intensification of low tropic species such as tilapias and carps is also utilising increasing amounts of such feeds. So called 'flow through' or 'open' intensive systems, in which there is little or no water re-use, can be highly polluting on receiving waters partly because the cost effective removal of dilute soluble nutrients is problematic. Open systems includes raceways and cages that produce most of the tilapias traded internationally (Coward \& Little, 2001).

Rapid global growth in farming fish and shrimp has occurred in tandem with strong commercial and environmental incentives to reduce the costs of feed and the impact of effluents respectively. Any review of the short history of aquaculture will illustrate that intensification is based on increasing the density of stocked animals stimulating increased use of both water exchange (to maintain water quality) and higher protein feeds. High water exchange aggravates nutrient loss and restricts opportunities for recycling these expensive inputs; it has also been linked to poor biosecurity and spread of disease in shrimp culture. This has caused a paradigm shift in recent years towards use of lower protein feeds in low exchange, green water systems, initially in shrimp production (McIntosh, 2000), but increasingly for other species. This approach appears to be particularly attractive for systems based on low trophic species such as the tilapias.

Recirculating aquaculture systems (RAS) are increasingly common land based systems in temperate countries in which water is reused after removal of waste nutrients and heat may be cost effectively retained in the system. The mechanisms for removal of suspended and dissolved wastes to reduce solids and nitrogenous compounds hazardous to fish are key parameters of RAS. There is no requirement for continual discharge of effluents into the environment, as is the case with the majority of conventional flow-through aquaculture systems. The 'price' to pay is the external energy cost of moving water through an appropriate water treatment system, temperature control, provision of adequate dissolved oxygen and need for complete balanced nutrition. The commercial culture of tilapia in RAS is now established in North America and parts of Europe as specialised enterprises targeting high value markets. Such operations have been either based on integration with waste heat or as stand-alone enterprises (Melard \& Philippart, 1981; Bunting \& Little, 2005). This factor together with the fact that they can produce food locally with few effluents suggests they meet some of the criteria of 'green' food production systems. The recent history of limited RAS development in the UK suggests that production technologies 
and markets are undeveloped; it is however established practice for value-added aquaculture such as accelerated production of juveniles for on-growing in open systems or ornamental production. Elsewhere in Europe they have become more established for catfish and eel production supplying diverse ethnic and cultural markets (Eding \& Kamstra, 2002). More limited access to water for UK and European aquaculture and growing regulation on effluents is likely to increase the attraction of RAS. Rapid production cycles for warmwater fish are also attractive. Tilapias can reach marketable size in as little as six months while 18-24 months is the norm for UK farmed rainbow trout (Oncorhynchus mykiss) or Atlantic salmon (Salmo salar). The extent of potential water and land productivity gains for tilapia cultured in RAS compared with other intensive production systems for warm-water and temperate species are highlighted in Table 1.

\section{Why tilapia, why intensive??}

Tilapias have many characteristics amenable to farming, such as its fast growth under a range of conditions, resilience against disease and a flavour and texture comparable with valuable marine fish (Beveridge $\&$ McAndrew, 2000). An ability to feed low in the food chain in principle means that production costs can be low but also, importantly, the fish can be marketed to appeal to increasingly informed consumers on environmental and broader ethical grounds. The trends towards more intensive practices by most commercial tilapia producers threatens these potential core advantages but is a response to current commercial realities.

An ability to feed low in the food chain is matched by a high responsiveness to intensification such that tilapias perform well in intensive systems based on complete, but relatively low protein diets. Their tolerance of high densities (lower densities in fact often trigger aggressive territorial behaviour) has meant a rapid uptake of more intensive operations including more use of higher quality supplementary feeds in semi-intensive ponds (Edwards, Yakupitiyage \& Lin, 2000) or complete, formulated feeds in intensive systems. Typically only $20-25 \%$ of fed protein is retained in the fish raised in intensive systems (Avnimelech, 2006) the balance becoming pollutants that must be removed. In principle if these waste nutrients could be retained in the system they become substrate for protein-rich bacteria that are re-ingested and utilised by the tilapia. Such nutrient recovery in situ occurs in conventional ponds but can be operated at a higher level of intensity through use of aeration to maintain microbial floc in suspension. These activated suspension ponds or technology (ASP, AST) have been advocated for both tilapias and shrimp (Avnimelech, Kochva \& Diab, 1994; McIntosh, 2000). The nutritional value of such microbial floc to aquatic animals is dependent on several factors: food preference, ability to both ingest and digest it but also the density of the suspended particles (Hargreaves, 2006). Tilapias being both capable of filter feeding and detritivory are ideal candidates for such systems (Dempster, Baird \& Beveridge, 1995; Azim, Verdegem, Mantingh, van Dam\& Beveridge, 2003).

Potentially the relative operational simplicity of AST can be combined with a production intensity that is economically viable in the context of a diversification option for mixed farms in the UK. Moreover the 'green' characteristics of the approach could be favourable especially as the market for premium ethical food of all 
types has developed rapidly but is under-supplied by local producers. The theoretical

\section{From feeding to floc}

Intensification of aquaculture systems imposes two major technical challenges-the maintenance of dissolved oxygen and the removal of inorganic nitrogenous products. The latter is critical within intensive aquaculture systems as even low levels of unionized ammonia in water are toxic to most cultured species (Timmons, Ebeling,Wheaton, Summerfelt \& Vinci, 2002). Oxygen levels typically become the limiting production factor in optimised culture-systems with adequate ammonia/ nitrite treatment capacity.

There are three principle nitrogen pathways to remove hazardous $\mathrm{N}$ species in aquaculture (1) photo-autotrophic removal by algae, (2) immobilisation by heterotrophic bacteria as proteinacious microbial biomass and (3) chemo-autotrophic oxidation to nitrate by 'nitrifying' bacteria (Ebeling et al., 2006). The relative importance of each varies with system type and production intensity. Hargreaves (2006) distinguishes between 'photosynthetic growth' (PSG) and 'mixed suspended growth' systems (MSG) based on the degree to which water quality is maintained by photosynthetic and bacterial processes. Suspended particulates formed by heterotrophic bacteria also provide efficient substrates for nitrifying bacteria in biofloc systems. These can be visualised as 'green' and 'brown' water systems.

Suspended-growth systems are further differentiated from 'attached growth' systems as the waste assimilation, recycling and food production occur within the culture unit as opposed to external bio-filters. Most aquaculture occurs in earthen ponds; which can be considered as PSG systems. Conversely, most RAS rely primarily on chemoautotrophic bacteria attached as aerobic bio-films on filter media. These examples reflect opposing management goals; in attached systems the aim is to remove nitrogen from the system. In suspended systems the aim is to conserve and recycle nitrogen as useful microbial biomass. Suspended growth systems have also been referred to by a range of terms based on biological or containment characteristics: activated suspension ponds (ASP) activated suspension technology (AST), bio-floc technology (BFT), organic detrital algae soup (ODAS) etc.

Intensification of any suspended growth system requires oxygenation and good water mixing to increase the rate of ammonia immobilisation, both of which can be achieved simultaneously through vigorous aeration. Phytoplankton-rich systems will also benefit from in-situ oxygen generation, but with intensification they will ultimately become light limited through self shading. Thus sustained aeration and mixing are essential requirements for intensification of both green and brown water systems.

Although few cross-references exist in the literature these processes are also the basis of the 'activated-sludge' sewage treatment process (Ganczarczyk, 1983; Thiel, 2002). The main difference is that bio-floc accumulations in sewage treatment systems are periodically settled and voided in a continuous or semi-continuous process. In closedAST the goal is to conserve bio-floc as a food source through internal nutrient 
recycling. This mode of operation has two further beneficial features. Theoretically, water exchange rates can be reduced compared to conventional RAS, which are themselves conservative consumers of water (Table 1). Secondly, accumulation of waste inorganic nitrogen compounds; unionised ammonia and nitrite $\left(\mathrm{NH}_{3}\right.$ and $\left.\mathrm{NO}_{2}\right)$ will result in growth inhibition or mortality of fish. In-situ heterotrophic ammonia and nitrite assimilation therefore also conserves water quality in this vital respect.

These attributes provided the impetus behind two major trends in the development and application of microbial bio-floc systems in aquaculture. The first has its origins in attempts to optimise natural feed production in semi-intensive ponds through various types of bio-manipulation. The second has its basis in the 'zero-water exchange' and water quality remediation possibilities of AST in contexts where water conservation is paramount. This driver had two threads. Researchers in Israel assessed AST as a potential means of simultaneously intensifying yields and water productivity in arid environments. Elsewhere, the same AST features, offered a means of addressing bio-security and environmental concerns associated with shrimp production. The development of intensive 'zero exchange' shrimp systems provided a highly effective means of disease and effluent management (Burford,Thompson, McIntosh, Bauman \& Pearson, 2004, Hari, Kurup, Varghese, Schrama, \& Verdegem, 2005; Lemonnier \& Faninoz, 2006; Samocha et al., 2007) with feed optimisation as a secondary benefit (Burford, Thompson, McIntosh, Bauman \& Pearson, 2003; Wasielesky, Atwood, Stokes\& Browdy, 2006). The concurrent evolution of these two drivers is considered below.

The limits of natural productivity in ponds were initially explored using input: output work (e.g. Schroeder, 1978) based on the premise that light-limited primary productivity of conventional shallow ponds in the Tropics of $30 \mathrm{~kg} \mathrm{ha}^{-1} \mathrm{~d}^{-1}$ could be further enhanced by optimising heterotrophic productivity through addition of carbon rich substrates. Initially, this approach assumed that photo-autotrophic and heterotrophic feed pathways were partitioned and emphasised the role of heterotrophic pathways in achieving further yield gains. However, the interdependence of these pathways and the mechanisms by which fish such as tilapia could filter feed or harvest micro-organisms from the water column soon became apparent (Colman \& Edwards, 1987; Avnimelech, Mokady \& Schroeder, 1989).

Concurrent work carried out in Israel on more intensive systems suggested that sorghum and other energy-rich grains could be used cost effectively as supplements to natural food-especially micro-algae rather than more protein-rich feeds (Hepher, 1988). Yields in these intensive water-limited systems, were constrained by water quality limits stimulating further work aimed at enhancing AST function. Theoretically, optimising ratios of $\mathrm{C}: \mathrm{N}$ will enhance conversion of toxic inorganicnitrogen compounds to microbial biomass available as food for fish or shrimp while further improving water quality. Goldman et al. (1987) elucidated the fundamental nutrient balance principles underlying growth efficiency of marine bacteria. They found $\mathrm{C}: \mathrm{N}$ ratios $>10: 1$ were optimal for optimising bio-floc production while minimising ammonia regeneration. Many investigators (Avnimelech et al, 1989, 1994, 1999, Hari et al., 2004, Burford et al, 2004) then applied this principle as an approach to optimising nutrient inputs and recycling within intensive bio-floc aquaculture systems. The use of a carbohydrate source in addition to conventional feeds or use of 
300 feeds with lower protein content was advocated on this basis for systems in which

301 bio-floc was aerated and retained in the system (Avnimelech, 1999).

302

303

304

305

306

307

308

309

310
The AST concept of further intensification of natural food production and use in situ has developed from this practice and theory for species such as tilapias and shrimp that are capable of utilising microbial floc as a major element of the diet and tolerating water high in suspended solids. Higher intensification rates also involve a move from earthen pond systems to lined-pond systems (shrimp) and tanks (tilapia). Most published accounts of AST however, relate to systems which maintain algal-rich water i.e. green water / PSG systems.

Generally green water systems are known to suffer inconsistent water quality, partly related to algal succession that is difficult to control or influence. Bacteria dominated systems tend to be more consistent (Hargreaves, 2006) but the nature and impacts of succession and change within systems with minimal phytoplankton are unknown. Our understanding of low-plankton systems is informed by the experience of managing partitioned aquaculture systems that alternate between autotrophic and heterotrophic status depending on ambient climate (Hargreaves, 2006). The principle of using compartments of algal rich water to remove ammonia is complicated by mixed success in controlling algal biomass.

The adaptation of these principles to a brown water / MSG system in light-limited conditions in which natural feed was mainly bacterial rather than derived from phytoplankton was the major objective of our research. The relative stability of heterotrophic microbial populations and their independence of light conditions on water quality were considered as positive factors (Avnimelech, 2006). For the sunlight-limited seasonal conditions in the UK the concept of well insulated smaller intensive tank-based systems located inside buildings was developed based on such a 'brown-water' approach. We now consider some of fundamental issues that differentiate AST as researched and promoted to date with their potential for use within the farming sector in the UK.

\section{Tilapia as a farm diversification strategy in the UK}

Intensive fish culture in the UK has been the preserve of an entrepreneurial business sector and the attraction of this type of diversification for risk-adverse farmers must be considered (Rosa, Kodithuwakku, Young \& Little, 2007). Diversification into a novel product (i.e. tilapia) based on a new technical approach (AST) is likely to further increase risk. The potential benefits of using AST for tilapia production rather than RAS scaled down to meet the investment profiles and potential local market niches available to them need to be established.

The costs and risks of maintaining optimal temperatures for warm-water fish are an initial concern to most potential adopters. The optimal temperature range for tilapia production is $28-32^{\circ} \mathrm{C}$, however, energy costs (heating and pumping) are proportionately low (15\% total direct costs; Timmons, 2005). In the past, RAS have often been linked to waste heat utilisation from distilleries, power stations, factories etc. Whilst an apparently green and cost-effective approach, over-reliance on third- 
party waste energy has also contributed to failures. A source of low value heat onfarm may be a motivation for diversification into warm-water fish culture. Another incentive is the utilisation of disused or underutilised agricultural buildings although low cost-purpose built structures such as insulated polytunnels also have potential.

Reducing the capital requirement and design complexity is an important advantage for any production system. In principle AST are simpler to design and manage than RAS; solids (feed and floc) are kept in suspension and dissolved oxygen levels maintained through aeration. As the culture unit also acts to treat wastes, there is no requirement for external biofilter, piping or pumps which results in lower capital costs and theoretically, more straight forward management. The capital outlay of these components for an RAS can range typically from 10-35\% of initial fixed costs. Low cost, simple AST could also be temporary or moveable structures allowing farmers to take advantage of seasonal availability of space, resources and marketing opportunities.

A potential incentive for producing tilapia using a microbial floc-based system rather than conventional RAS is the possibility that local feeds can be used. The overall reduction in feedstock quality required to raise tilapia in AST is potentially a substantial saving on production costs over RAS in which feed cost typically make up from $30-40 \%$ of total operating costs depending on the scale of the operation and other factors (Timmons et al., 2002, Timmons, 2005).Using a feed of lower overall quality feed i.e. $20 \%$ crude protein feed rather than typical formulations $(28-32 \% \mathrm{CP})$ could reduce reliance on feed ingredients such as fish meal and soybean meals. Potentially it could open opportunities for growing or using feed ingredients locally or on-farm in a similar manner to that practiced for intensive dairy production thus reducing risk and enhancing familiarity that were important priorities for potential adopters (Rosa et al., 2007).

Over-ambitious production schedules, steep technical learning curves and lack of prior aquaculture experience have been inter-related causes of recurrent failure in RAS. Contract farming packages which emphasise potential gains while underestimating risk has contributed to spectacular failures in other novel farm diversification start-ups (e.g. ostrich, and Alpaca farming). Research indicates a similar threat in the UK tilapia sector. Small-scale modular approaches hold potential for limiting risks carried by new adopters with no previous aquaculture experience. These adopters then have the option of scaling up to more economically efficient units required to supply higher volume/ low margin commodity chains (food processors and supermarkets), or continuing to produce smaller volumes of fresh product for higher value niche markets. In the US, innovative tilapia production initially targeted value added markets but relatively high labour costs undermined their capacity to compete with imports leading them to target specialist live sales, often to ethnic minorities (Serfling, 2000). Significant scale-up in production of tilapia and other species such as Pangasius spp. in tropical countries threatens competitiveness of producers in the commodity sector in the UK.

A key research question is; can such a production approach be maintained at production levels that would be cost effective and attractive to farmers in the UK? The use of aquatic microbial floc as the basis for tilapia production has been advocated, but research on intensive indoor/ brown-water production systems is still 
400 required to justify promotion of the AST approach to farmers in temperate climates 401 such as the UK.

\section{Comparing performance of AST and RAS}

There is a recent history of research on the operation and efficiency of AST systems, most of which is based on intensively fed, green water systems in ponds or tanks (reviewed by Hargreaves, 2006). Most of the commercial application appears to relate to the relatively much lower-density shrimp production with relatively little published information regarding higher density fish production systems (Avnimelech, 2007). Unfortunately there is a dearth of data for replicated large-scale research systems and most conclusions have been drawn based on either short term small-scale experiments and/or observation of commercial or semi-commercial systems based on variable sized fish (Table 2). Only two trials (Rakocy, Bailey, Thoman \& Shultz, 2002, Murray et al., 2007) report on-growing to the minimum harvest size of $400 \mathrm{~g}$ feasible for markets in the UK. Most reports have emphasised the potential for improved feeding efficiency based on nutrient recycling in AST systems compared to RAS or conventional pellet-fed ponds (Avnimelech et al, 1989; Milstein, Avnimelech, Zoran \& Joseph., 2001). Avnimelech (2006) for example cites feed: cost ratios in C:N manipulated pond-AST as being almost double control systems with higher crude dietary protein inclusion. However, meaningful evaluation of the commercial potential of AST compared to RAS also requires knowledge of fish growth rates and system carrying capacities. Unfortunately key parameters that would allow interpretation of growth are often lacking (e.g. water temperature) or inadequately presented. In particular crude daily weight gain rather than specific growth rates are routinely used for comparisons using fish of highly variable stocking and harvest weights.

Even allowing for these limitations the magnitude of difference between growth rates is evident. Under controlled temperatures, stocking and feed conditions with C:N manipulation and solids removal, Murray et al (2007) found growth rates in AST were only $68 \%$ of those achievable in RAS (achieving an SGR of $2.8 \%$ for fish grown from $19 \mathrm{~g}-405 \mathrm{~g}$; both systems fed on $30 \%$ CP diets). SGRs fell to $36 \%$ of RAS levels in AST fed on 18\% CP diets. When one accounts for the slower growth rate of larger-fish, grow-out time to $400 \mathrm{~g}$ is almost doubled in the fastest growing AST compared to the RAS control (Murray et al., 2007).

Low carrying capacities make the commercial case for intensive AST appear still more marginal. Stocking densities exceeding $100 \mathrm{~kg}_{\text {fish }} \mathrm{m}^{-3}$ are routinely achievable in RAS with oxygenation and densities up to $70-80 \mathrm{~kg}$ fish m${ }^{-3}$ with aeration

(Timmons et al., 2002). This compares to reported levels of only $10-16.5 \mathrm{~kg}^{-3}$ ish m $\mathrm{m}^{-3}$ in AST (Table 2). Murray et al. (2007) achieved levels of $28 \mathrm{~kg}$ fish m $\mathrm{m}^{-3}$, but only using complete feeds and solids removal. Clearly the benefits of feed and water use efficiencies reported for AST need to be viewed in the context of growth inhibition and reduced carrying capacity in intensive systems. Both factors have consequences for overall production costs when capital and variable costs for building size, floor area, insulation, labour and heating etc. are considered. The same constraints also eliminate gains in water efficiency; Murray et al. (2007) and Rakocy et al. (2002) measured broadly comparable optimal rates of 7.2 and $9.7 \mathrm{~kg} \mathrm{~m}^{-3}$ achievable in AST compared to typical RAS rates of $8-10 \mathrm{~kg} \mathrm{~m}^{-3}$ (Tables 1 and 2). 
451 The potential for further intensification appears to be fundamentally limited by

452 biological factors which correlate with bio-floc concentration in closed systems.

453 Hargreaves (2007) observed process instability at feeding levels above $200 \mathrm{~g} \mathrm{~m}^{-3}$

454 equivalent to a stocking density of $10 \mathrm{~kg} \mathrm{~m}^{-3}$ (at a feed rate of $2 \%$ bw day ${ }^{-1}$ ). Rakocy

455 et al. (2002) and Murray et al. (2007) observed severe growth inhibition and increased

456 mortality at TSS levels above $850 \mathrm{mg} \mathrm{l}^{-1}$. In practice therefore, there is a requirement

457 for solids removal in AST to maintain a level of suspended solids which will not

458 significantly retard food intake and growth or constrain economically viable stocking

459 densities. This requires some form of external clarifier (Murray et al., 2007;

460 Hargreaves, 2006; Rakocky et al., 2002). However, the variable quality (size,

461 consistency and specific gravity) of microbial floc that occurs over time complicates

462 the design and operational management of such clarifiers in indoor AST systems

463 (Murray et al., 2007).

464

465

466

467

468

469

470

471

472

473

474

475

476

477

478

479

480

481

482

483

484

485

486

487

488

489

490

491

492

493

494

495

496

497

Operation of AST incorporating solids removal also represents a partial step-back towards RAS-type compartmentalisation with semi-continuous or continuous water re-circulation. Solids settled in external clarifiers could be removed or managed entirely independently for controlled release to the grow-out compartment. Investigators found floc composition varied in closed culture-systems with implications for chronic and acute event-mortalities (Murray et al., 2007; Azim. Little \& North., 2007; Rakoky et al, 2002). Compartmentalisation could also provide a means of floc-stabilisation potentially incorporating activated-sludge techniques borrowed from the water and sanitation sector where steady-state operation is a critical feature. One commercial producer in the United States has already moved along this route in a hybrid system; maintaining TSS within 70-130 $\mathrm{mg}^{-1}$ and achieving net yields of $60 \mathrm{~kg} \mathrm{~m}^{-3}$ year ${ }^{-1}$ (Serfling, 2000); in other words, resorting to use of bio-floc primarily as a low-cost in-situ water treatment process with low water exchange requirements.

The fundamental theoretical benefit of AST; improved feed efficiency can also be challenged. Analysis of feed and crude protein conversion and retention indicate that the amounts of microbial floc in a brown water system utilised as feed over a range of commercial stocking densities in fish offered feeds of a range of quality and presentational form were minimal (Murray et al., 2007). This contrasts markedly with the values published by Avnimelech (1999) based on observations of light-driven AST systems but could reflect differences in interpretation of data. Attempts to manage microbial floc production by manipulating $\mathrm{C}: \mathrm{N}$ ratio, or floc levels through solid removal are also highly variable in the systems described. Azim et al (2007) also reported increased feed conversion efficiency in AST compared to RAS systems in which fish were maintained at low densities and fed similar amounts of feed confirming the utilisation of microbial floc by fish.

There are other important characteristics of tilapia culture in AST that deserve mention. The specific conditions of AST appear to favour beneficial bacteria and reduce disease incidence compared to alternative systems. The absence of disease in AST systems has been related to the probiotic nature of microbial floc (Serfling, 498 
The natural habitat of tilapias are turbid water lakes of Africa but the high levels of suspended solids that characterise AST has raised issues regarding the welfare and taste of the fish produced in such systems. The impacts of high levels of microbial floc in AST systems on the taste and welfare of tilapias has been recently assessed. Off-flavours are related to the absorption and accumulation of natural chemicals or compounds (such as geosmin and MBT) through the gills, skin or gastrointestinal tract of fish (Boyd \& Tucker. 1998; Gautier et al., 2002). Contrary to common perception culture systems rich in natural food are not necessarily more likely to produce fish with off-flavour (Serfling, 2000; Eves, Turner, Yakupitiyage, Tongdee, \& Ponza, 1995). Bue (2005) conducted organoleptic taste trials on fish raised in both RAS and AST and found no perceived differences among fish direct from tanks or after standard depuration techniques in fresh or saline water (Rungreungwudhikrai,1995).

Generally high levels of suspended solids are related to poor fish welfare as indicated by poor growth, fusion of gill lamellae (Mettam, 2005) and susceptibility to bacterial or parasite infections (Noble \& Summerfelt, 1996).Lower feed intakes and performance withstanding, Vincent (2006) found no indication of gill damage on fish raised over extended periods within AST or RAS systems nor differences in tail erosion, scale loss etc characteristic of poor welfare.

\section{Future research needs}

Assessment of the development process towards an intensive system for UK farmers to produce and market an exotic food fish species has identified a number of interesting issues. Prototype RAS systems now require testing with potential producers and this will require an iterative action learning approach whereby insights of the adopters are incorporated. Studies on the nature of entrepreneurship give some insight as to the characteristics of potential adopters and whether diversification was driven by need or opportunism (Rosa et al., 2007).

Clearly there are trade-offs in terms of environmental and broader ethical values of fish produced by RAS and AST. Both systems have very limited effluents which through virtue of their nutrient concentration are useful fertilisers (Watten, \& Busch, 1984; McMurtry et al., 1997). Further research to quantify the potential synergisms between water and nutrient use in tank based systems and associated high value horticulture is required. Integration with hydroponics has particular market potential as demand for closed cycle, pesticide-free fruit and vegetables increases.

Although fish produced in AST systems had few overt signs of poor welfare, the lower feed intake, slower individual growth and chronic mortalities observed suggest that RAS provided more consistent and optimal conditions. Further development of mixed systems has been advocated in which culture units are partitioned with algae, microbial floc and/or periphyton (e.g. Avnimelech, 2006; 2007; Azim and Little, 2006; Serfling, 2000). Optimisation of floc levels for commercial applications is a research priority.

The value of microbial floc in terms of preventing fish disease problems warrant scientific investigation. Probiotic approaches are now widespread in the market but 
the relative control possible in AST and observations of the high health of fish produced makes further investigation worthwhile.Designs in which the natural feed component can be optimised with respect to nutritional quality and energy efficient ingestion, digestion and assimilation should be prioritised. Development with producers in an action research mode is most likely to result in models which are management efficient and adoptable.

Intensive tilapia production is land efficient (Table 1) and may be located in periurban, rather than rural locations. Benefits include the improved access to a range of consumers, potentially reducing marketing costs. Controlled environments leading to improved predictability of production and expected genetic and feeding gains as has occurred in the broiler industry over the longer term are expected to further improve competitiveness compared with other fish species and substitutes (Timmons, 2005)

The market context for tilapia sales in the UK is dynamic. Consumers are increasingly willing to try new preparations and species of fish (Seafish, 2006b), whether it be for health reasons, indulgence or environmental grounds. Potential for tilapia therefore exists, not only in ethnic markets as a fresh or live alternative to frozen imports, but as a locally available 'green' fish product possibly with ecocredentials (Young, et al, 2006). Tilapia also has potential in the food service sector, where novel, exciting fish products are of interest, particularly if they have amenable aesthetic and preparation qualities (Seafish, 2006a). A locally available, small-scale and high quality tilapia supply would therefore meet industry wide interest in fresh, traceable fish supplies, however, a comparative analysis of the relative competitiveness of tilapias produced locally against imports and substitutes is required.

\section{Acknowledgements}

This work has been supported by the Rural Economy Land Use Programme of Research Councils UK under the project 'Warmwater Warm water fish production as a niche production and market diversification strategy for arable farmers with implications for sustainability and public health'. Ekram Azim is supported by a Marie Curie Fellowship of the EU (Contract MIFI-CT-2005-008965). The authors thanks the staff of Nam Sai farm, Prachninburi, Thailand for their support during the project.

\section{References}

Avnimelech, Y. (2006).Bio-filters. The need for a new comprehensive approach. Aquaculture Engineering, 34 172-178.

Avnimelech, Y. (2007). Feeding with microbial flocs by tilapia in minimal discharge bio-flocs technology ponds. Aquaculture, 264,140-147. 
Avnimelech, Y. (1999). Carbon/nitrogen ratio as a control element in aquaculture systems, Aquaculture, 176, 227-235.

Avnimelech, Y, Mokady, S and Schroeder, G.L. (1989).Circulated ponds as efficient bioreactors for single cell protein production Israel J.Aquaculture Bamidgeh, 41, 5866.

Avnimelech, Y, Kochva, M \& Diab, S. (1994) Development of controlled intensive aquaculture systems with a limited water exchange and adjusted carbon to nitrogen ratio.Israel J.Aquaculture Bamidgeh, 46,119-131.

Avnimelech, Y. \& Bejarano, I.(2007). Probiotic effects of bio-floc technology: Depression of Streptococci Infection of tilapia http://floc.aesweb.org/library/sanantonio2007/avinemelech.pdf

Azim,M.E., Verdegem, M.C.J., Mantingh, I., van Dam, A.A. \& Beveridge, M.C.M.(2003). Ingestion and utilization of periphyton grown on artificial substrates by Nile tilapia Oreochromis niloticus L. Aquaculture Research, 34, 85-92.

Azim, M. E. \& Little, D.C. (2006). Intensifying aquaculture production through new approaches to manipulating natural food. CAB Reviews: Perspectives in Agriculture, Veterinary Science, Nutrition and Natural Resources, . 1, no.062, 23p URL http://www.cababstractsplus.org/cabreviews/index.asp DOI $\underline{10.1079 / P A V S N N R 20061062 ~}$

Azim, M.E., Little, D.C., North, B.P., 2007. Growth and welfare of Nile tilapia Oreochromis nilotiucs cultured in indoor tanks using Activated Suspension Technique (AST). World Aquaculture 2007, San Antonio, Texas, USA, 26 February-3 March, 2007

Belton, B. Little, D.C. \& Grady, K. in press Reassessing Sustainable Aquaculture through the Lens of Tilapia Production in Central Thailand, Rural Sociology

Beveridge, M. \& McAndrew, B. Eds. (2000). Tilapias: Biology and Exploitation. Kluwer Academic Publishers, Dordrecht, Netherlands.

Beveridge, M.C.M.\& Little, D.C. (2002). History of aquaculture in traditional societies.p.3-29. In Ecological Aquaculture (Ed. B.A. Costa-Pierce) Blackwell Science, Oxford.

Boyd, C.E. \& Tucker, C.S. (1998. Pond aquaculture water quality management. Kluwer academic publishers. Boston, MA .

Britton, S. (2006). Omega-3 gives health foods something to shout about, Food Manufacture, 81, 14.

Bue, C.E. (2006). Evaluation of welfare and organoleptic criteria of Nile Tilapia (Oreochromis niloticus) grown in Activated Suspension Technology Systems. Thesis. University of Stirling, Stirling, U.K. 
648 Bunting, S.W. \& .Little, D.C. (2005) The emergence of Urban aquaculture in Europe.

649 Chapter 8 In B.A. Pierce, P.Edwards, D.Baker \& A. Desbonnet (Eds).Urban

650 Aquaculture pp.119-136. Wallingford, UK. CABI Publishing

651

652 Burford, M.A., Thompson, P.J., McIntosh R.P., Bauman, R.H. \& Pearson D.C.

653 (2003) Nutrient and microbal dynamics in high-intensity, zero-exchange shrimp

654 ponds in Belize. Aquaculture 219, 393-411.

655 Burford, M.A, Thompson, P.J., McIntosh, R.P, Bauman, R.H.\& Pearson, D.C. 656 (2004). The contribution of flocculated material to shrimp (Litopenaeus vannamei) 657 nutrition in a high-intensity, zero-exchange system. Aquaculture, 232, 525-537.

658

659

660

661

662

663

664

665

666

667

668

669

670

671

672

673

674

675

676

677

678

679

680

681

682

683

684

685

686

687

688

689

690

691

692

Colman, J.A.\& Edwards, P. (1987). Feeding pathways and environmental constraints in waste-fed aquaculture:Balanc and optimization In D.J.W Moriarty \& R.S.V. Pullin (Eds) Detritus and Microbial Ecology in Aquaculture (pp. 240-281)ICLARM Conference proceedings 14, Manila, Philippines, ICLARM.

Coward, K and Little, D.C. (2001). Culture of the aquatic chicken; present concerns and future prospects. Biologist 48 (1).

Dempster, P., Baird, D. J., \& Beveridge, M. (1995).Can fish survive by filter-feeding on microparticles?- Energy balance in tilapia grazing on algal suspensions, Journal of Fish Biology, 47, 7-17.

Ebeling, J.M., Timmons, M.B. \& Bisogni, J.J. (2006). Engineering analysis of the stoichiometry of photoautotrophic, autotrophic, and heterotrophic removal of ammonia-nitrogen in aquaculture systems. Aquaculture, 257, 346-358.

Eding, E \& Kamstra, A. (2002). Netherlands farms tune recirculation systems to production of varied species. Global Aquaculture Advocate, 5, 52-55.

Edwards, P., Yakupitiyage, A \& Lin, C.K. (2002). Semi-intensive pond aquaculture. M.C.M Beveridge \& B.J. Mc Andrew (Eds) Tilapias:Biology and exploitation (pp.377-403) Dordrecht, Kluwer Academic Publ.

Ellingsen, H. \& Aanondsen, S. A. (2006). Environmental Impacts of Wild Caught Cod and Farmed Salmon - A Comparison with Chicken, International Journal of Life Cycle Analysis, 11, 60-65.

Eves, A., Turner, C., Yakupitiyage, A., Tongdee, N.\& Ponza, S., (1995). The microbiological and sensory quality of septage-raised Nile Tilapia (Oreochromis niloticus). Aquaculture, 132, 261-272.

FAO (2007a). The State of World fisheries and Aquaculture 2006, Food and Agriculture Organisation of the United Nations 693 
FAO (2007b). Fisheries Global Information System, Global Aquaculture Production Tilapia, Food Agriculture Organisation of the United Nations, www.fao.org

Foran, J., Carpenter, D., Hamilton, M., Knuth, B., \& Schwager, S. J. (2005). RiskBased Consumption Advice for Farmed Atlantic and Wild Pacific Salmon Contaminated with Dioxins and Dioxin-like Compounds. Environmental Health Perspectives, 113, 552-556.

Foran, J., Good, D., Carpenter, D., Hamilton, M., Knuth, B., \& Schwager, S. J. (2005). Quantitative Analysis of the Benefits and Risks of Consuming Farmed and Wild Salmon. Journal of Nutrition 135,2639-2643.

Ganczarczyk, J. (1983). Activated sludge process: theory and practice. Pollution engineering and technology series; No. 23. Marcel and Decker Inc. New York.

Goldman, J.C., Caron, D.A.\& Dennett, M.R., (1987). Regulation of gross growth efficiency and ammonium regeneration in bacteria by substrate $\mathrm{C}: \mathrm{N}$ ratio. Limnology and Oceanography 32, 1239-1252.

Grimm, C.C., Lloyd, S.W. \& Zimba, P.V., (2004). Instrumental versus sensory detection of off-flavours in farm-raised channel catfish. Aquaculture, 236, 309-319.

Hargreaves, J. A. (2006). Photosynthetic suspended-growth systems in aquaculture Aquacultural Engineering, 34, 344-363.

Hargreaves A\& Wong, H. W, (2007). The effect of solids concentration on performance of a bio-floc system for tilapia. Paper presented at Aquaculture 2007. Sustainable Aquaculture session, San Antonio Texas.

Hari, B., Kurup, B.M., Varghese, J.T., Schrama, J,W.\& Verdegem, M.C.J. (2006). The effect of carbohydrate addition on water quality and the nitrogen budget in extensive shrimp culture systems. Aquaculture, 252, 248-263.

Hepher, B. (1988). Nutrition of Pond Fishes., Cambridge, Cambridge University Press.

Huntingford, F.A., Adams, C., Braithwaite, V.A., Kadri, S., Pottinger, T.G., Sad Øe, P. \& Turnbull, J.F. (2006). Current issues in fish welfare. Journal of Fish Biology 68, 332-372.

Josupeit, H. (2005), World Market of Tilapia, Globefish, FAO, Rome.

Josupeit, H. (2007a) Tilapia Market Report-China, March 2007, Globefish, FAO, Rome.

Josupeit, H. (2007b) Tilapia Market Report, June 2007, Globefish, FAO, Rome. 
Lemmonier, H. Faninoz, S. (2006). Effect of water exchange on effluent and sediment characteristics and on partial nitrogen budget in semi-intensive shrimp ponds in New Caledonia. Aquaculture Research, 37, 938-948.

Little, D.C. (2006). A new approach to tilapia in the UK-based on activated suspension technology and niche markets. Aquaculture Today 28-30 th March 2006 Edinburgh

MacIntosh, R.P. (2000). Changing paradigms in shrimp farming: IV:low protein feeds and feeding strategies. Global Aquaculture Advocate 2, 40-47.

Marine Conservation Society (2002). Good Fish Guide. www.mcsuk.org.

McMurtry, M.R., Sanders, D.C., Cure, J.D., Hodson, R.G., Haning, B.C. \& St Amand, P.C. (1997). Efficiency of water use of an integrated fish/vegetable co-culture system, Journal of the World Aquaculture Society 4, 420-428.

Melard, C. \& Philippart, J.C. (1981). Pisciculture intensive du tilapia Saratherodon niloticus dans less effluents thermiques d'une centrale nucleaire en Belgique. In K.Tiews (Ed) Proceedings of the World Symposium on Aquaculture in heated effluents ad recircualtion systems. Volume 1 (pp 637-659.) 28-30 ${ }^{\text {th }}$ May 1980 Stavanger, Berlin, Heenemann.

Mettam, J. (2005). An investigation into the use of gill pathologies in rainbow trout (Oncorhynchus mykiss) as a welfare score reflecting water quality. Thesis. University of Stirling., Stirling, U.K.

Milstein, A., Avnimelech, Y., Zoran, M. and Joseph, D. (2001). Growth performance of hybrid bass and hybdrid tilapia in conventional and active suspension ponds. The Israeli Journal of Aquaculture 53, 147-157.

Murray, F.J and Little, D.C. (2007). Evaluation of a commercial-scale activated suspension production system for intensive tilapia culture in indoor tanks. In Press

National Fisheries Institute (2007) Top 10 US Consumption By Species www.aboutseafood.com

Naylor, R.L., Goldburg, R.J., Primavera, J.H., Kautsky, N., Beveridge, M.C.M., Clay, J., Folke, C., Lubchenco, J., Mooney, H.\& Troell, M. (2000). Effect of aquaculture on world fish supplies. Nature, 405, 1017-24.

Noble, A.C. \& Summerfelt, S.T. (1996). Disease encountered in rainbow trout cultured in recirculating system. Annual Review of Fish Diseases 6, 65-92.

Rakocy, J.E. (2002) An integrated fish and field crop system for arid areas In. B.A. Costa Pierce (Ed) Ecological Aquaculture:The evolution of the Blue Revolution (pp.263-285).Oxford, UK. Blackwell Science. 
Rakocy, J.E., Bailey, D.S., Thoman E.S.\& Shultz, R.C. (2005). Intensive tank culture of tilapia with a suspended, bacterial-based, treatment process. University of the Virgin Islands. http://ag.arizona.edu/azaqua/ista/ista6/ista6web/pdf/584.pdf . 13pp

Rosa, P., Kodithuwakku, S., Young, J.A. \& Little, D. (2007). Opportunity, necessity \& entrepreneurial success: a farming perspective, Proceedings in 4th ASGE International Entrepreneurship Research Exchange, February 6-9 ${ }^{\text {th }}, 2007$, Brisbane, Australia.

Royal Commission on Environmental Pollution (2004). Turning The Tide: Addressing the impact of fisheries on the marine environment. Summary Report.

Rungreungwudhikrai, E.O. (1995). Characterization and classification of off-flavour of Nile tilapia. Thesis AE-95-29. Asian Institute of Technology. Bangkok, Thailand.

Samocha,T.M., Patnaik,S., Speed, M., Ali, A.M.,Burger, J.M., Almeida,R.V., Ayub, Z., Harisanto, M., Horowitz, A. \& Brock, D.L. ( 2007 ).Use of molasses as carbon source in limited discharge nursery and grow-out systems for Litopenaeus vannamei Aquacultural Engineering, 36, 184-191.

Schroder, G.L. (1978). Autotrophic and heterotrophic production of microorganisms I intensively manured fish ponds and related fish yields. Aquacultur,e 14 303-325.

Seafish (2006). Foodservice Market Update August 2006, Seafish Industry Authority. www.seafish.org.

Serfling, S.A. (2000). Closed-cycle, controlled environment systems: The solar aquafarms story. The Advocate, June 48-51.

Thiel D.J. (Ed.) (2002). Activated Sludge, WEF Manual of Practice No. OM-9. Water and Environment Federation, Alexandria.

Timmons, M.B. (2005). Competitive potential for USA urban aquaculture. In B. Costa-Pierce, A. Desbonnet, P.Edwards and D. Baker (Eds) Urban Aquaculture (pp.137-157) Wallingford, UK/Cambridge, Massachusetts:CABI Publishing.

Timmons, M.B., Ebeling, J.M., Wheaton, F.W., Summerfelt, S.T,. Vinci, B.J. (2002). Recirculating Aquaculture Systems, $2^{\text {nd }}$ Edition. Caruga Aqua Ventures, New York, USA.

Verdegem, M.C.J., Bosma, R.H.\& Verreth, J.A.J. (2006). Reducing water use for animal production through aquaculture. International Journal of Water Resources Development 22(1), 101-113.

Vincent, Y.R. (2006). Use of gill condition to assess welfare of tilapia raised in two intensive production systems. Thesis. University of Stirling, Stirling, U.K.

Wasielesky, W., Atwood, H., Stokes, A., Browdy, C. (2006). Effect of natural production in a zero exchange suspended microbial floc based super-intensive culture system for white shrimp Litopenaues vannamei. Aquaculture, 258, 396-403. 
841 Watten, B.J., \& Busch, R.L.(1984).Tropical production of tilapia (Sarotherodon

842 aurea) and tomatoes (Lycopersicon esculentum) in a small-scale recirculating water

843 system. Aquaculture, 4, 271-283

844 White, K., O'Neill, B., \& Tzankova, Z. (2004). At a Crossroads: Will Aquaculture

845 Fulfil the Promise of the Blue Revolution? SeaWeb. http://www.seaweb.org/home.php

846

847

848

Worm, B., Barbier, E. B., Beaumont, N., Duffy, E., Folke, C., Helpern, B. S.,

849 Stachowicz, J. J., \& Watson, R. (2006)., Impacts of Biodiversity Loss on Ocean

850 Ecosystem Services, Science, 314, 787-790.

851

852 Young, J.A., Grady, K., Little, D., Watterson, A. \& Murray, F. (2006).

853 Multidisciplinary Perspectives on an Emergent Fish Product: The Tank of British

854 Tilapia. (10 pp) In: Proceedings of the Thirteenth Biennial Conference of the

855 International Institute of Fisheries Economics \& Trade, July 11-14, 2006,

856 Portsmouth, UK.

857

858 
859

860

861

862 